\title{
Taxes and Subsidies on Agricultural Producers as Elements of Intersectoral Transfer of Resources: Magnitude of the Transfer and Search for Policy Options
}

\author{
Sarfraz Khan Qureshi, Ejaz Ghani and \\ Muhammad Mushtaq*
}

\section{INTRODUCTION}

Public policies in many diverse fields have implications for the transfer of resources between sectors. Administered agricultural prices, taxes, subsidies, an overvalued currency and protection provided to producers are examples of some of the policies that have been used by many governments in mobilizing resources for development. From the vantage point of assessing the past performance and development prospects of the agricultural sector, it is useful to have an idea about the direction and extent of the resource transfer from this sector. The knowledge of the policy instruments used to bring about the transfer is also important. While the size of the transfer is a measure of the overall incentives being provided, the tools used for the transfer have unique implications for efficiency, equity and growth outcomes. The purpose of the paper is confined to: (i) an estimation of the magnitude of the transfer for the period 1972-73 to 1986-87; and (ii) identification, in broad terms, of the direction that the restructured public policies may take.

\section{NET FISCAL BURDEN}

The fiscal burden on agricultural producers takes into account open and concealed taxes and subsidies affecting agricultural producers in both output and input

*The authors are respectively, Joint Director and Staff Economists at the Pakistan Institute of Development Economics, Islamabad. They are grateful to Professor Syed Nawab Haider Naqvi, Director, Pakistan Institute of Development Economics for continued inspiration and stimulating discussions. The authors are also grateful to Dr Abdul Salam, Division Chief, Agricultural Prices Commission and Dr Muhammad Hussain Malik, Senior Research Economist, PIDE, for their useful suggestions and comments. The paper is an abridged version of the paper presented in the Fifth Annual General Meeting of the Pakistan Society of Development Economists. The reader is referred to the original paper for a complete description of the nature of open and concealed taxes and subsidies affecting the agriculture sector and for the estimation procedures used in the computation of the value of resource transfers. 
Second, although the yield from direct taxes on land and/or agricultural produce has not declined in absolute terms yet it shows a declining trend when measured as a proportion of agricultural value added. The expectations of some observers that Ushr may in due course become a significant source of revenue for poverty alleviation projects in rural areas may not be realized in the light of experience of the past five years. The assessments of, and collections from Ushr, have been much lower than the estimated potential of this tax. The inelasticity of the direct taxes on agriculture is a major structural weakness in the tax structure.

Third, the revenue from taxes on agricultural commodities from export duties and/or from the profits of state trading corporations has been large in some years. However, this source of revenue exhibits a large measure of instability and cannot be relied on to finance development programmes on a continuing sustained basis.

Fourth, concealed taxation on agricultural commodities due primarily to trade and exchange rate policies has been heavy. Like export duties, it is also an unstable source of revenue. In fact, in some years, the level of concealed taxation transforms itself into subsidies to farmers. At the disaggregated commodity levels, this source of revenue provides distorted incentives for farmers. Nominal Protection Coefficients for different commodities imply widely divergent rates of taxation or subsidization for crops. These coefficients for given crops also change over time.

Fifth, open subsidies on inputs have grown in magnitude over time. The government has eliminated subsidies on plant protection, seeds and some other minor items. There is also a stated government policy goals regarding the elimination of fertilizer subsidies. Despite this goal, subsidies on fertilizers in the terminal year are high. There was a restraint on the growth of fertilizer subsidies during 1981-82 to $1984-85$ but this restraint seemed to have been relaxed in the last two years of the study.

Sixth, concealed subsidies on irrigation, credit and electrified tube-wells have increased significantly over the period of the study. Water and Power Development Authority (WAPDA), through fuel adjustment charges, has been successful in eliminating the subsidy on electricity for the agricultural sector in some years. In the budget for 1988-89, some steps in restraining the credit subsidy on production loans have been announced. However, the singular policy failure has been in the area of the subsidy on irrigation. The sharp increase in operation and maintenance expenses for the upkeep of the vast canal system is warranted. The subsidies on account of irrigation sub-head can be restrained only if the water rates are increased.

\section{BROAD DIRECTIONS FOR POLICY REFORMS}

Our discussion on policy options for the taxation of the agricultural sector would remain on the general level of broad principles as it is difficult to suggest 
concrete reforms when the bulk of the existing taxes and subsidies are concealed. However, our finding that there has been an increasing trend of resource flow into agriculture resulting in increased agricultural incomes suggestes a need for a more intensive taxation of agriculture in Pakistan. The burden of direct taxes has shown a sharp declining trend despite the introduction of $U s h r$ since 1982-83. The indirect taxes on agricultural exports through export taxes and the profits of government export corporations have been used for the stabilization of prices and incomes rather than a device for raising revenue for the government treasury. The yield from these revenue heads has shown a large measure of instability and no rising trend. The subsidies on agricultural inputs have also increased both in absolute terms and relative to the value added in the agricultural sector. Despite a float ing exchange rate, the Rupee has remained overvalued by about 20 percent. However, the extent of the overvaluation is much less than was the case prior to the massive devaluation of the Rupee in 197.2. The extent of concealed taxation through artificially low domestic prices for farm produce has also been reduced and/or turned into subsidization by a closer alignment of domestic prices to world prices.

While the case for a more intensive taxation of agriculture can easily be made in view of the increased taxable capacity of the sector, the question arises as to the appropriate method of taxing the agricultural sector. There is a need to review and reduce the level of both open and concealed subsidies on most agricultural inputs. The subsidies on inputs which require to be popularized among the farming community may, however, continue for a limited time only. An overvalued currency and export duties are simple to administer but have large adverse effects on resource use efficiency. Taxes of this type should be discontinued. A tax on the value of land, an old favourite of economists, needs to be made use of on a much larger scale than has been the case in the past. The land tax is generally not shiftable. It encourages owners of unused land to either use the land productively or sell it to other people who will make productive use of the newly acquired land. The administrative and political feasibility of the proposal needs to be established by a detailed and in-depth study, however.

\section{REFERENCES}

Appleyard, Dennis R. (1987). "Report on Comparative Advantage". Islamabad: Agricultural Prices Commission. (APCOM Series No. 61)

Cheong, Kee Cheok, and Emmanuel H. D'Silva (1984). "Prices, Terms of Trade and the Role of Government in Pakistan's Agriculture". Washington, D.C.: The World Bank. (World Bank Staff Working Paper No. 643).

Gotsch, Carl, and Gilbert Brown (1980). "Prices, Taxes and Subsidies in Pakistan Agriculture, 1960-76". Washington, D.C.: The World Bank. (World Bank Staff Working Paper No. 387)

\section{Comments on}

"Taxes and Subsidies on Agricultural Producers as Elements of Intersectoral Transfer of Resources: Magnitude of the Transfer and Search for Policy Options"

I would like to thank the organizers of the meeting for inviting me to discuss an interesting paper. Taxes and subsidies on agriculture, which is the subject of the paper, have increasingly engaged the attention of economists, lately as the budget deficit has assumed alarming proportions and the search for new options for resource mobilization has become quite intense.

I compliment the authors for having collected the vast amount of dat relating to various types of taxes and subsidies, from various scattered sources, and analysing their incidence.

\section{Open Taxation of the Agriculture Sector}

The authors have identified the following instruments of direct taxation of agriculture in Pakistan: (i) Land Tax (ii) Agricultural Income Tax; and (iii) Ushr which directly affect the farmers' incomes.

In their discussion of direct taxes on agriculture, the authors have rightly pointed out that agricultural income tax, as currently in vogue in Pakistan, is misnamed and confusing as it is not a tax on agricultural incomes but a graduated surcharge on land revenue collected from the farmers.

The authors have correctly argued that yield from the land tax have declined over time as with the introduction of Ushr in 1982, farmers paying Ushr were exempted from the payment of land revenue. Nevertheless, it may be noted that inspite of the exemption from land revenue payments, granted to those paying Ushr, the revenue from land tax did not fall that rapidly as was expected initially. It has been pointed out that the Ushr collection during the last five years has bee about 86 percent of the assessment and only 20 percent of the reported potentia yield from this levy. However, the most relevant issue relating to $U$ sh $r$ in the contex of resource mobilization and development financing is can the revenues collected from the Ushr levy be used for financing general Government expenditure and development programmes. This issue merits serious thought by those who are well 
versed with the subject. To my understanding the uses of Ushr money have been prescribed and may not be changed.

\section{Taxes on Agricultural Crops}

While discussing taxes on agricultural crops the authors have discussed various commodity cesses such as sugar-cane and cotton cesses, export duties on cotton and rice. In addition, they have included the profits or losses of the Cotton Export Corporation (CEC) and Rice Export Corporation of Pakistan (RECP) in their discussion on the subject. This inclusion of profits and losses of the RECP and CEC along with various commodity cesses needs reconsideration. The authors mention the instability of the revenues from the commodity cesses and the profit and loss of CEC and RECP. This instability stems partly from the fluctuations in commodity production and partly from the prices prevailing in international markets. The falling international prices of rice and cotton besides the high incidentals of the CEC and RECP were also responsible for the losses incurred by these corporations.

\section{Indirect Taxes Paid by Agricultural Consumers}

While apportioning the share of agriculture from the indirect taxes representing import duties, sales taxes, etc. the distinction between farm population and rural population needs to be kept in view as the farm population is only a subset of the rural population. It is significant to note that the incidence of indirect taxes paid both in terms of per capita and as a percentage of value added in agriculture has increased considerably over time.

\section{Concealed Taxation of Agriculture}

Concealed taxation of agriculture has been generally practised through an overvalued exchange rate and paying domestic producers prices less than that providing in the international market. To provide the evidence for such taxation, the authors have relied mainly in calculating the Nominal Protection Coefficients (NPCs) for wheat, basmati rice, IRRI rice, cotton and sugar-cane.

It may be emphasised here that NPCs, although relatively simple to comprehend and calculate, nevertheless need to be interpreted rather carefully. An NPC greater than one in the case of farm commodities does not necessarily imply protection or subsidy to the producers for the following reasons as the domestic border prices comprise at least 3 major components i.e. (i) cost of the produce, (ii) marketing and processing expenses and (iii) transport and handling expenses. Thus, higher NPCs could very well result from the high expenses entailed in marketing, processing, etc.
The institutional arrangements for the exports, of farm produce etc. in Pakistan are not very efficient involving very high expenses and have frequently resulted in higher values of the resulting NPCs.

\section{Open and Concealed Subsidies to Farmers}

The authors point out that the size of the subsidy to the producer is measured by the difference between the value of output at domestic prices and the value of output at world prices. The economic subsidy on various inputs, at least on those that are tradeable such as fertilizers and pesticides and seed need to be worked out by following the above definition. The economic subsidies need to be differentiated from the budgetary subsidies as well and need to be treated separtely. The authors have mainly relied on the budgetary subsidies and ignored the concept of economic subsidy.

Following the definition of economic subsidies, it would be really interesting to find out that in case of fertilizers, pesticides etc. (i) what part of the subsidy has been meant for the farmers? (ii) what proportion has gone to the industry? and, (iii) what percentage was due to the tied aid by the donors? These are, I think, important questions and have not been touched upon in the paper.

The authors mention that the subsidy involved in irrigation water charges could be calculated by comparing the prices of water charged by the Government with either the marginal cost of tube-well water or the market prices of tubewell water. I have some reservations to the use of this approach for the following reasons:

(i) There is no single cost of tube-well water as it is likely to vary across various regions. The flexibility in the use of tube-well water is much greater while canal water use is characterized by institutional rigidities.

(ii) As regards the operation and maintenance $(\mathrm{O} \& \mathrm{M})$ charges, it needs to be borne in mind that most of the water development projects are multi-purpose and what really are the $O \& M$ charges for irrigation is a question of judgement.

(iii) The irrigation network is a part of the socio-economic infrastructure and are we charging the users of other infrastructure accordingly?

(iv) To what extent are $O \&$ M charges a real and to what extent are they padded?

(v) Should the farm sector be charged and penalized for the inefficiencies and dubious practices of the irrigation and power departments?

At the end, I would like to point out that the proposal of instituting tax on the value of land, by the authors, needs to be spelled out and carefully looked into. 
I believe there is an urgent need for investment of time and resources to find out further avenues of mobilising resources.

Abdul Salam

Agricultural Prices Commission, Islamabad 